\title{
PENYELESAIAN MASALAH MATEMATIKA BERAKHIR TERBUKA PADA SISWA SMA
}

\author{
Jackson Pasini Mairing 1)* dan Henry Aritonang ${ }^{2)}$ \\ ${ }^{1), 2)}$ Pendidikan Matematika FKIP \\ Universitas Palangka Raya \\ *jacksonmairing@gmail.com
}

\begin{abstract}
Abstrak
Kemampuan berpikir tingkat tinggi ditunjukkan oleh kemampuan siswa dalam memecahkan masalah yang memiliki jawaban atau cara penyelesaian lebih dari satu. Masalah demikian disebut masalah berakhir terbuka. Penelitian ini bertujuan mendeskripsikan kemampuan siswa SMA kelas XI dalam menyelesaikan masalah berakhir terbuka. Penelitian ini dilaksanakan menggunakan pendekatan campuran kuantifatif dan kualitatif (blended quntitative-qualitative approach) dengan jenis penelitian deskriptif. Subjeknya adalah 40 siswa kelas XI dari salah satu SMAN di kota Palangka Raya, Kalimantan Tengah. Peneliti memberikan instrumen penelitian yaitu dua masalah matematika berakhir terbuka pada materi lingkaran dan garis singgung lingkaran kepada semua subjek. Masing-masing masalah menuntut siswa untuk menyelesaikan dengan dua cara berbeda. Cara pertama pada masalah bagian (a), dan cara kedua pada bagian (b). Penyelesaian dari setiap subjek diskor menggunakan rubrik holistik. Hasil penelitian menunjukkan rata-rata skor kemampuan siswa dalam memecahkan masalah sebesar 4,63 (maksimum skor =16) jika dikonversi ke skala 100 menjadi 28,9.. Hanya ada 1 dari 40 siswa (2,5\%) yang mampu menyelesaikan Masalah 1 dengan dua cara berbeda. Pada Masalah 2, ada 92,5\% yang mampu menyelesaikan dengan satu cara tertentu tetapi belum mampu menyelesaikan dengan cara lainnya. Jadi, tidak ada siswa yang memiliki kemampuan berpikir tertinggi dalam matematika yaitu berpikir kreatif. Kondisi tersebut terjadi karena penyelesaian siswa pada masalah berakhir terbuka hanya didasarkan pada rumus atau prosedur tertentu.
\end{abstract}

Kata Kunci: berpikir kreatif, masalah matematika, masalah berakhir terbuka, pemecahan masalah

\section{PENDAHULUAN}

Tujuan utama siswa belajar termasuk dalam matematika adalah memiliki kebiasaan berpikir produktif dan sikap yang baik. Berpikir produktif itu sendiri terdiri dari berpikir kritis dan kreatif (Marzano, Pickering, \& McTighe, 1993). Kedua berpikir tersebut tergolong berpikir tingkat 
tinggi (high order thinking skills) (King, Goodson, \& Rohani, 2016). Berpikir kritis didefinisikan sebagai berpikir yang diarahkan untuk memecahkan masalah matematika. Berpikir kreatif didefinisikan sebagai berpikir yang diarahkan untuk menemukan jawaban berbeda atau cara lain dalam memecahkan masalah (Krulik, Rudnick, \& Milou, 2003; Matlin, 1994; Sternberg \& Sternberg, 2012). Berdasarkan definisi tersebut, berpikir kreatif merupakan kemampuan berpikir tertinggi, Kedua berpikir tersebut dapat diperoleh siswasiswa melalui belajar memecahkan masalah matematika.

Masalah berbeda dengan soal rutin. Soal rutin adalah soal yang cara memperoleh jawabannya segera dapat dilihat oleh siswa. Caranya dengan menggunakan secara langsung suatu konsep, rumus atau prosedur tertentu (Hudojo, 2005). Contoh pertama dari soal rutin adalah "sebutkan rumus pythgoras?". Siswa segera dapat menjawab soal tersebut dengan memanggil pengetahuan yang telah diingat sebelumnya. Soal yang demikian menuntut siswa memiliki kemampuan berpikir memanggil. Contoh keduanya adalah "jika panjang sisisisi penyiku dari segitiga siku-siku adalah 6 $\mathrm{cm}$ dan $8 \mathrm{~cm}$, tentukan panjang sisi miringnya?". Siswa segera dapat menentukan jawabannya dengan mensubstitusi bilangan-bilangan yang diketahui ke rumus pythagoras. Soal yang demikian menuntut siswa memiliki kemampuan berpikir dasar. Berpikir memanggil dan dasar disebut berpikir tingkat rendah (low order thinking skills) (Krulik, Rudnick, \& Milou, 2003).

Masalah matematika adalah soal yang menantang dimana cara penyelesaiannya tidak segera dapat dilihat oleh siswa (Polya, 1973; Posamenteir \& Krulik, 2009). Siswa tidak segera melihat caranya karena jawaban dari masalah tidak dapat diperoleh dengan menggunakan secara langsung suatu konsep, rumus atau prosedur tertentu. Siswa perlu mengelaborasi pemahaman terhadap masalah dan pengetahuan sebelumnya untuk mengembangkan cara penyelesaian. Pengetahuan tersebut adalah konsep-konsep yang termuat dalam masalah, pendekatan/strategi pemecahan masalah, dan pengalaman sebelumnya dalam memecahkan masalah (Mairing, Budayasa, \& Juniati, 2011). Selain itu, siswa perlu membentuk gambar mental untuk memahami masalah, dan merepresentasikan masalah dalam bentuk gambar, diagram atau tabel (Sternberg \& Sternberg, 2012).

Ada dua jenis masalah matematika yaitu masalah berakhir terbuka (open-ended problem) dan masalah tertutup (closed problem). Masalah berakhir terbuka adalah masalah dengan jawaban atau cara penyelesaian lebih dari satu (Bush \& Greer, 1999). Contohnya adalah:

\section{Masalah 1}

a. Suatu lingkaran $x^{2}+y^{2}-2 a x-8 y+$ $16=0$ menyinggung garis $x=6$. Tentukan nilai $a$.

b. Adakah cara lain untuk menentukan nilai $a$ ? Jika ada, selesaikan dengan cara tersebut.

\section{Masalah 2}

a. Tentukan persamaan garis singgung lingkaran $x^{2}+y^{2}=9$ dengan gradien 1.

b. Adakah cara lain untuk menentukan garis singgung tersebut? Jika ada, selesaikan dengan cara tersebut.

Masalah tertutup adalah masalah dengan jawaban atau cara penyelesaian tepat satu (Bush \& Greer, 1999). Contoh adalah: 


\section{Masalah 3}

Tentukan persamaan garis yang tegak lurus dengan garis yang melalui titik $(0,1)$ dan $(3,0)$, dan garis tersebut membagi lingkaran $x^{2}+y^{2}-4 x+6 y+9=0$ sama besar.

Pada Masalah 1 dan 2, siswa diminta untuk menyelesaikan lebih dari satu cara. Masalah yang demikian mendorong siswa memiiki kemampuan berpikir kreatif. Dengan demikian, masalah berakhir terbuka dapat membantu siswa memiliki kemampuan berpikir tertinggi yaitu berpikir kreatif.

Bukan hanya itu, penyelesaian masalah membutuhkan waktu dan usaha berulang-ulang. Terkadang siswa belum dapat menyelesaikan masalah pada waktu pertama kali. Siswa perlu belajar dan mencoba beberapa kali untuk menyelesaikannya hingga jawaban benar diperoleh. Proses tersebut membuat siswa memiliki sikap tekun dan pantang menyerah. Peraih medali OSN bidang Matematika tingkat SMP memikirkan kembali masalah yang belum dapat diselesaikannya (Mairing, Budayasa, \& Juniati, 2012). Proses tersebut dapat membantu siswa-siswa memiliki sikap tekun dan pantang menyerah. Sikap-sikap lain yang dapat dikembangkan melalui belajar menyelesaikan masalah-masalah matematika adalah percaya diri dalam situasi yang tidak biasa, keingintahuan yang besar, dan mampu berkomunikasi baik lisan maupun tulisan (Ministry of Education, 2006; National Council of Teachers of Mathematics [NCTM], 2000; Ontario Ministry of Education, 2006).

Pentingnya masalah khusunya masalah berakhir terbuka belum sejalan dengan fakta di sekolah-sekolah. Hasil penelitian mengenai kemampuan siswasiswa kelas X MIPA dari salah satu SMA Negeri di kota Palangka Raya, Kalimantan
Tengah dalam memecahkan masalahmasalah matematika pada materi SPLTV (Sistem Persamaan Linear Tiga Variabel) menunjukkan bahwa ada 3,1\% siswa yang tergolong pemecah masalah yang kurang berpengalaman (naive problem solvers), $96,9 \%$ tergolong pemecah masalah yang rutin (routine problem solvers), dan tidak ada siswa yang tergolong pemecah masalah yang baik (good problem solvers). Ini berarti tidak ada siswa menulis penyelesaian yang benar (Mairing, 2017).

Hasil penelitian lainnya pada ssiwa kelas X SMAN di Sidoarjo, Jawa Timur juga menunjukkan hal serupa dimana siswa yang tergolong tidak kreatif, kurang kreatif, cukup kreatif, kreatif, dan sangat kreatif secara berturut-turut sebanyak 44,4\%, 50\%, 2,8\%, $2,8 \%$, dan $0 \%$. Tingkat kreatif siswa berkaitan erat dengan kemampuannya dalam memecahkan masalah. Dengan demikian, siswa yang tergolong kreatif dan sangat kreatif dapat digolongkan sebagai siswa yang memiliki kemampuan pemecahan masalah yang baik. Hasil penelitian tersebut menunjukkan siswa-siswa yang tergolong pemecah masalah yang baik sebanyak 2,8\% (Mahendra, 2015).

Kondisi tersebut perlu diperbaiki. Langkah awal untuk itu adalah guru perlu terlebih dahulu mengetahui kemampuan siswa-siswanya dalam memecahkan masalah berakhir terbuka. Kemampuan tersebut diukur menggunakan rubrik holistik pemecahan masalah (Bush \& Greer, 1999). Selanjutnya, guru perlu memahami penyelesaian yang dibuat siswa untuk mengidentifikasi hal-hal yang belum dimiliki dan perkembangan kemampuan siswa dalam memecahkan masalah berakhir terbuka. Kedua hasil tersebut dapat dijadikan dasar bagi guru untuk mengembangkan rencana pembelajaran yang dapat membantu siswa memiliki 
kemampuan pemecahan masalah khususnya berakhir terbuka. Penelitian ini dimaksudkan untuk mendeskripsikan kemampuan penyelesaian masalah matematika terbuka pada siswa kelas XI MIPA dari salah satu SMAN di kota Palangka Raya, Kalimantan Tengah.

\section{METODE PENELITIAN}

Penelitian ini dilaksanakan menggunakan pendekatan campuran kuantifatif dan kualitatif (blended quntitative-qualitative approach) dengan jenis penelitian deskriptif. Ada lima tahap dalam penelitian ini (Ary, Jacobs, \& Sorensen, 2006). Tahap pertama adalah peneliti menentukan populasi yaitu siswa MIPA dari salah satu SMAN di kota Palangka Raya, Kalimantan Tengah. Sekolah tersebut merupakan salah satu sekolah favorit di Palangka Raya dengan akreditasi A. Ada 5 kelas MIPA di sekolah tersebut.

Tahap kedua, peneliti mengambil 1 kelas sebagai sampel menggunakan penarikan sampel acak bergerombol (clustered random sampling). Sampelnya adalah kelas XI MIPA 1. Ada 40 siswa di kelas tersebut dengan perincian 12 laki-laki dan 28 perempuan.

$\begin{array}{clr}\text { Tahap } & \text { ketiga, } & \text { peneliti } \\ \text { mengembangkan } & \text { instrumen } & \text { penelitian }\end{array}$ berupa dua masalah berakhir terbuka. Kedua masalah tersebut adalah Masalah 1 dan 2 pada bagian pendahuluan. Masalah yang digunakan dalam penelitian ini lebih menekankan pada cara penyelesaian berbeda yang ditunjukkan oleh pertanyaan (b) di setiap masalah.

Tahap keempat, peneliti membagikan kedua masalah tersebut pada semua siswa di kelas sampel yaitu XI MIPA 1. Semua siswa disediakan waktu selama 1 jp (45 menit) untuk menyelesaikannya. Kedua masalah dalam penelitian ini dijadikan soal ulangan harian siswa pada materi lingkaran kelas XI. Tujuannya agar siswa diharapkan belajar terlebih dahulu sebelum menyelesaikan kedua masalah tersebut karena skornya dijadikan nilai di sekolah, dan menghindari siswa tidak bisa menyelesaikan masalah karena lupa atau tidak belajar.

Tahap terakhir, peneliti menganalisis data. Caranya setiap penyelesaikan siswa diskor menggunakan rubrik holistik pemecahan masalah (Bush \& Greer, 1999; Charles, Lester, \& O'Daffer, 1987; Sa'dijah \& Sukoriyanto, 2015). Skor yang dihasilkan dapat digunakan untuk mengukur kemampuan siswa dalam memecahkan masalah berakhir terbuka. Selanjutnya, peneliti mengidentifikasi cara yang digunakan siswa dalam memecahkan masalah berakhir terbuka dalam penelitian ini. Hasil identifikasi digunakan untuk mendeskripsikan hal-hal yang belum dimiliki siswa dalam memecahkan masalah berakhir terbuka.

Tabel 1. Rubrik Holistik Pemecahan Masalah

\begin{tabular}{|c|c|}
\hline Skor & Deskripsi \\
\hline 0 & $\begin{array}{l}\text { a. Siswa tidak menulis penyelesaian } \\
\text { apa pun, } \\
\text { b. Siswa menulis yang diketahui dan } \\
\text { ditanya, tetapi tidak menunjukkan } \\
\text { pemahaman terhadap masalah. }\end{array}$ \\
\hline 1 & $\begin{array}{l}\text { a. Siswa menulis yang diketahui dan } \\
\text { ditanya dengan benar, dan ada } \\
\text { tulisan penyelesaian tetapi cara } \\
\text { penyelesaiannya tidak sesuai. } \\
\text { b. Siswa telah berusaha untuk } \\
\text { mencapai subtujuan, tetapi belum } \\
\text { berhasil. } \\
\text { c. Siswa menjawab dengan benar, } \\
\text { tetapi tidak ada caranya. }\end{array}$ \\
\hline 2 & $\begin{array}{l}\text { a. Siswa menggunakan cara yang } \\
\text { tidak sesuai dan jawabannya } \\
\text { salah, tetapi penyelesaiannya } \\
\text { menunjukkan } \\
\text { terhadap masalah. }\end{array}$ \\
\hline
\end{tabular}


FIBONACCI : Jurnal Pendidikan Matematika dan Matematika. Vol. 4 (1), pp: 61-70.

\begin{tabular}{|c|c|}
\hline Skor & Deskripsi \\
\hline & $\begin{array}{l}\text { b. Siswa menulis jawaban yang } \\
\text { benar, tetapi caranya tidak dapat } \\
\text { dipahami atau salah. }\end{array}$ \\
\hline \multirow[t]{4}{*}{3} & $\begin{array}{l}\text { a. Siswa telah menerapkan cara yang } \\
\text { sesuai, tetapi salah memahami } \\
\text { bagian tertentu dari masalah, atau } \\
\text { mengabaikan kondisi tertentu dari } \\
\text { masalah. }\end{array}$ \\
\hline & $\begin{array}{l}\text { b. Siswa telah menerapkan cara } \\
\text { penyelesaian yang sesuai, tetapi - } \\
\text { (i) menjawab masalah secara } \\
\text { tidak benar tanpa penjelasan, } \\
\text { atau }\end{array}$ \\
\hline & $\begin{array}{l}\text { (ii) tidak menuliskan } \\
\text { jawabannya. }\end{array}$ \\
\hline & $\begin{array}{l}\text { c. Siswa menuliskan jawaban benar } \\
\text { dan telah memilih cara } \\
\text { penyelesaian yang sesuai, tetapi } \\
\text { penerapannya tidak sepenuhnya } \\
\text { benar. }\end{array}$ \\
\hline 4 & $\begin{array}{l}\text { a. Siswa telah menggunakan cara } \\
\text { penyelesaian yang sesuai, } \\
\text { menerapkannya dengan benar, dan } \\
\text { menulis jawaban yang benar. }\end{array}$ \\
\hline & $\begin{array}{l}\text { b. Siswa menggunakan cara yang } \\
\text { sesuai, menulis jawaban yang } \\
\text { benar, tetapi ada sedikit kesalahan } \\
\text { dalam perhitungan. }\end{array}$ \\
\hline
\end{tabular}

\section{HASIL DAN PEMBAHASAN}

Peneliti membagikan Masalah 1 dan 2 kepada semua subjek dibantu oleh guru matematika kelas XI MIPA 1 pada tanggal 12 Februari 2018 pukul 10.00 - 10.45. Penyelesaian siswa pada Masalah 1(a), 1(b), 2(a) dan 2(b) diskor menggunakan rubrik holistik dengan rentang skor $0-4$. Hasilnya menunjukkan rata-rata skor kemampuan siswa dalam memecahkan masalah sebesar 4,63 (Tabel 2) dimana maksimum skor setiap siswa sebesar $4 \times 4=16$. Jika dikonversi rata-rata tersebut ke skala 100 menjadi 28,9 .

Tabel 2. Ringkasan Data Hasil Penelitian

\begin{tabular}{lrrr}
\hline Masalah & $\begin{array}{c}\text { Rata- } \\
\text { rata }\end{array}$ & $\begin{array}{c}\text { Mini- } \\
\text { mum }\end{array}$ & $\begin{array}{c}\text { Maksi- } \\
\text { mum }\end{array}$ \\
\hline $1(a)$ & 0,65 & 0 & 4 \\
$1(b)$ & 0,13 & 0 & 4 \\
$2(a)$ & 3,83 & 1 & 4 \\
2(b) & 0,03 & 0 & 1 \\
Keseluruhan & 4,63 & 1 & 13 \\
\hline
\end{tabular}

Rata-rata skor tertinggi ada pada masalah 2(a) sebesar 3,83 yang menunjukkan bahwa sebagian besar siswa telah menjawab dengan benar (memperoleh skor 4) pada masalah tersebut. Persentase siswa tersebut sebanyak 92,5\% (Tabel 3). Lebih lanjut, persentase siswa yang memperoleh skor 0 pada masalah 1(b) dan 2(b) secara berturut-turut sebesar $95 \%$ dan 97,5\%. Hal tersebut menunjukkan bahwa sebagian besar siswa belum bisa menyelesaikan masalah 1 dan 2 dengan cara penyelesaian yang berbeda.

Tabel 3. Banyak dan Persentase Siswa di Setiap Masalah

\begin{tabular}{ccccc}
\hline Skor & \multicolumn{4}{c}{ Masalah } \\
\cline { 2 - 5 } & $\mathbf{1 ( a )}$ & $\mathbf{1 ( b )}$ & $\mathbf{2 ( a )}$ & $\mathbf{2 ( b )}$ \\
\hline 0 & 27 & 38 & 0 & 39 \\
& $(67,5 \%)$ & $(95 \%)$ & & $(97,5 \%)$ \\
1 & 2 & 1 & 2 & 1 \\
& $(5 \%)$ & $(2,5 \%)$ & $(5 \%)$ & $(2,5 \%)$ \\
2 & 10 & 0 & 0 & 0 \\
& $(25 \%)$ & & & \\
3 & 0 & 0 & 1 & 0 \\
4 & 1 & 1 & $(2,5 \%)$ & \\
4 & $(2,5 \%)$ & $(2,5 \%)$ & $(92,5 \%)$ & 0 \\
& & &
\end{tabular}

\section{Penyelesaian Masalah 1(a) dan 1(b)}

Hanya ada 1 siswa yaitu YD yang memperoleh skor 4 pada Masalah 1(a) dan 1(b). Cara pertamanya didasarkan pada representasi dari masalah dalam bentuk gambar lingkaran. Awalnya, YD menentukan titik pusat lingkaran, dan menulis titik pusat “ $P(a, 4)$ ”. Selanjutnya, 
siswa tersebut menentukan jari-jari lingkaran, dan menulis jari-jari " $r=a$ ". YD menggambar lingkaran dengan titik pusat dan jari-jari yang diperoleh sebelumnya bersama dengan garis singgung $x=6$. YD menjawab $r=a=3$ didasarkan pada gambar tersebut (Gambar 1). Cara keduanya didasarkan pada titik pusat, jari-jari, dan pemahamannya terhadap konsep diskriminan. Pertama, YD menentukan titik pusat dengan cara berbeda yaitu pemfaktoran. Kedua, YD mensubstitusi garis singgung $x=6$ ke persamaan lingkaran. Ketiga, YD menentukan nilai $a$ dengan memanfaatkan diskriminan dari suatu garis yang menyinggung suatu kurva tertentu adalah $D=0$, dan memperoleh jawaban $a=3$ (Gambar 2).

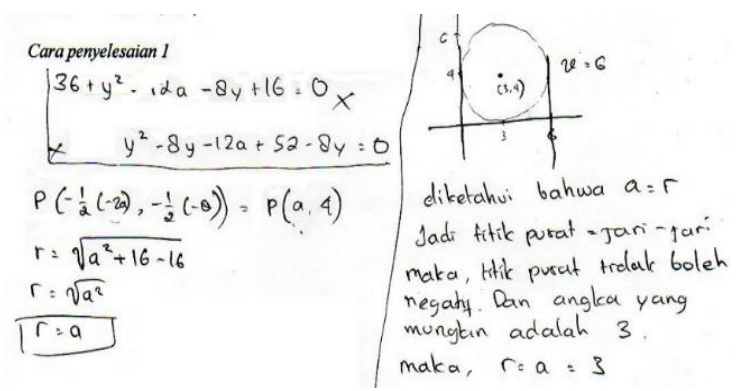

Gambar 1. Penyelesaian Siswa YD pada Masalah 1(a)

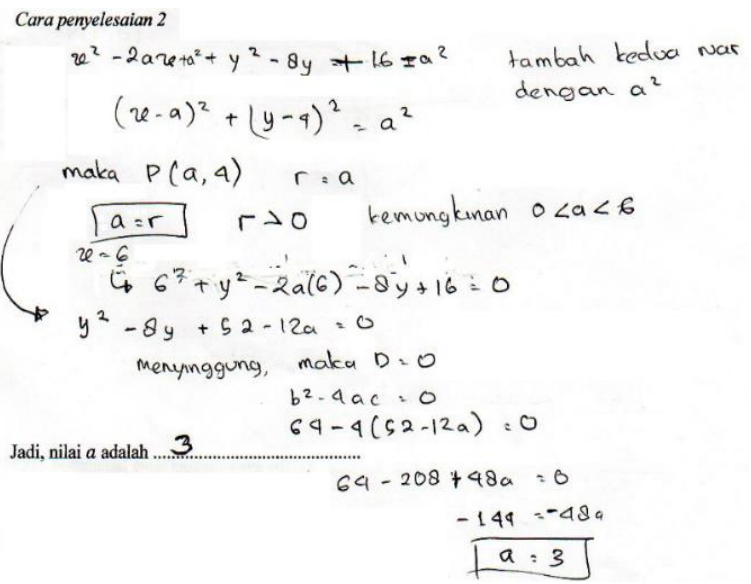

Gambar 2. Penyelesaian Siswa YD pada Masalah 1(b)
Ada 10 siswa yang memperoleh skor 2 pada Masalah 1(a), tetapi tidak ada yang memperoleh skor 2 pada Masalah 1(b). Ada 5 dari 10 siswa tersebut yang menjawab benar $(a=3)$ tetapi caranya tidak bisa dipahami. Siswa GO sudah berhasil memfaktorkan persamaan pada Masalah 1(a) ke dalam bentuk umum $(x-a)^{2}+$ $(y-b)^{2}=r^{2}, \quad$ walaupun tidak menunjukkan proses pemfaktoran tersebut. GO juga telah memasukkan $x=6$ ke persamaan lingkaran tetapi alasannya mengganti suku $y^{2}-8 y+16$ dengan $16-$ $32+16$ tidak bisa dipahami (Gambar 3). Lima siswa lainnya mampu memperoleh $r=a$ atau melanjutkannya dengan cara yang tidak bisa dipahami. Salah satunya yaitu siswa NF telah memasukkan $x=6$ ke persamaan dan memperoleh persamaan $y^{2}-8 y-12 a=-52$. Akan tetapi, NF belum mampu melanjutkannya karena tidak memanfaatkan diskriminan $D=0$ untuk memperoleh jawaban $a=3$ (Gambar 4).

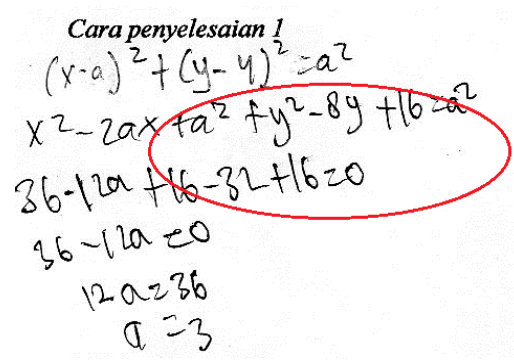

Gambar 3. Penyelesaian Siswa GO pada Masalah 1(a)

$$
\begin{aligned}
& \text { Cara penyelesaian } 1 \\
& \begin{array}{l}
P=\left(-\frac{1}{2} A,-\frac{1}{2} B\right)=\left(-\frac{1}{2}(-2),-\frac{1}{2}(-8)\right)=(a, 4) \\
r=\sqrt{\left(-\frac{1}{2} A\right)^{2}+\left(\frac{1}{2} B\right)^{2}-C}=\sqrt{a^{2}+4^{2}-16^{0}}=\sqrt{a^{2}+16-16}=\sqrt{a^{2}}=a \\
x^{2}+y^{2}-2 a x-8 y+16=0 \\
6^{2}+y^{2}-2 a \cdot 6-8 y+16=0 \\
36+y^{2}-12 a-8 y+16=0 \\
y^{2}-8 y-12 a=-52
\end{array}
\end{aligned}
$$

Gambar 4. Penyelesaian Siswa NF pada Masalah 1(a) 
Lebih lanjut, ada 2 siswa yang memperoleh skor 1 karena jawaban dan cara yang digunakannya salah. Salah satunya adalah siswa YG yang memasukkan $x=6$ dan $y=0$ ke persamaan lingkaran pada masalah. YG seharusnya hanya memasukkan persamaan garis singgung $x=$ 6 , tidak perlu mensubstitusi $y=0$ walaupun titik-titik yang terletak pada garis $x=6$ memiliki $y=0$ (Gambar 5).

$$
\begin{aligned}
x=6 \quad y=0 \\
x^{2}+y^{2}-2 a x-8 y+16=0 \\
6^{2}+0^{2}-2 \cdot a \cdot 6-8 \cdot 0+16=0 \\
36+0-12 a+16=0 \\
36-12 a+16=0 \\
52-12 a=0 \\
52=129 \\
\frac{52}{12}=9 \\
4,3=a
\end{aligned}
$$

Gambar 5. Penyelesaian Siswa YG pada Masalah 1(a)

\section{Penyelesaian Masalah 2(a) dan 2(b)}

Ada 37 dari 40 siswa yang memperoleh skor 4 (menjawab benar) pada Masalah 2(a). Akan tetapi, penyelesaiannya didasarkan pada rumus di buku teks yaitu $y=m x \pm r \sqrt{1+m^{2}}$ (Gambar 6).

$$
\begin{aligned}
& r=\sqrt{9} \\
& r=3 \\
& =y^{2}=m u \pm r \sqrt{1+m^{2}} \\
& =1 u \pm 3 \sqrt{1+1^{2}} \\
& =1 u+3 \sqrt{2} \text { atau } \quad u-3 \sqrt{2}
\end{aligned}
$$

Gambar 6. Penyelesaian Siswa AR pada Masalah 2(a)

Hanya ada 1 siswa yang memperoleh skor 3 pada Masalah 2(a) yaitu MN. Siswa tersebut telah menggunakan cara yang sesuai tetapi rumus yang digunakan tidak menggunakan kemungkinan ke-2 dari jawaban yaitu $y=$ $m x-r \sqrt{1+m^{2}}$. Awalnya siswa salah menulis 9 sebagai $r$ (yang dilingkari pada
Gambar 7), tetapi baris berikutnya benar yaitu $r=3$.

$$
\begin{aligned}
& y=m+v \sqrt{m^{2}+1} \\
& y=1 x+9 \sqrt{1^{2}+1} \\
& y=x+3 \cdot \sqrt{2} \\
& y=x+3 \sqrt{2} \\
& -x+y-3 \sqrt{2}=0 x-1 \\
& x-y+3 \sqrt{2}=0
\end{aligned}
$$

Gambar 7. Penyelesaian Siswa MN pada Masalah 2(a)

Lebih lanjut, ada 2 siswa yang memperoleh skor 1. Kedua siswa menuliskan penyelesaian tetapi cara yang digunakan tidak sesuai atau tidak bisa dipahami (Gambar 8).

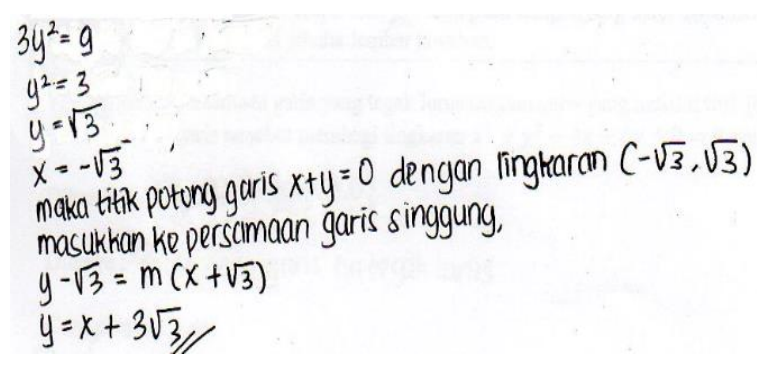

Gambar 8. Penyelesaian Siswa ES pada Masalah 2(a)

Terakhir, hanya ada 1 siswa yang menjawab Masalah 2(b) yaitu YD yang memperoleh skor 4 pada Masalah 1(a), 1(b) dan 2(a). YD telah membuat representasi dalam bentuk gambar lingkaran dan garis singgungnya, tetapi garis yang digambarnya memiliki gradien $m=-1$ padahal yang diketahui $m=1$ (Gambar 9).

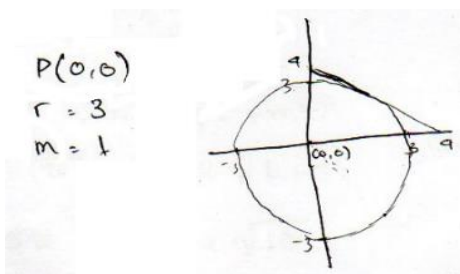

Gambar 9. Penyelesaian Siswa YD pada Masalah 2(b) 
Tingkat kemampuan berpikir tertinggi dalam matematika adalah berpikir kreatif. Siswa memiliki kemampuan berpikir ini ditunjukkan oleh kemampuannya dalam menyelesaikan masalah dengan cara berbeda atau menentukan jawaban lainnya. Hasil penelitian ini menunjukkan bahwa hanya ada 1 siswa yang mampu menyelesaikan Masalah 1 dengan dua cara berbeda (memperoleh skor 4 di Masalah 1(a) dan 1(b)). Siswa tersebut juga memperoleh skor 4 pada Masalah 2(a), tetapi memperoleh skor 1 di Masalah 2(b).

Lebih lanjut, 39 siswa lainnya belum mampu memperoleh skor 4 pada Masalah 1(a). Hal berbeda dengan Masalah 2(a) dimana 92,5\% siswa memperoleh skor 4 . Perbedaan ini terjadi karena siswa harus memahami masalah dan merepresentasikannya dalam bentuk gambar untuk memahami Masalah 1(a). Siswa yang tidak bisa melakukan aktivitas kognitif tersebut, tidak akan mampu menyelesaikannya (Polya, 1973). Pada Masalah 2(a), siswa tidak harus melakukan aktivitas tersebut karena ada rumus yang dapat digunakan secara langsung untuk menentukan jawabannya. Hasil penelitian ini menunjukkan kondisi tersebut dimana 97,5\% siswa tidak merepresentasikan kondisi dari masalah dengan gambar lingkaran. Penyelesaian siswa tersebut didasarkan pada rumus-rumus yang ada di buku teks. Siswa demikian akan mengalami kesulitan jika ada kondisi di luar konteks rumus tersebut, atau cara penyelesaian masalah yang menuntut siswa mengelaborasi antar pengetahuan. Hal tersebut yang membuat $97,5 \%$ siswa belum dapat memperoleh skor 4 pada Masalah 1(a).

Selain itu, tidak ada rumus yang dapat digunakan secara langsung untuk menyelesaikan Masalah 1(a). Siswa perlu mengelobarasi antar pengetahuan untuk mengembangkan rencana penyelesaian. Rencana tersebut merupakan tahap terpenting kedua dalam menyelesaikan masalah. Rencana penyelesaian itu sendiri dipengaruhi oleh pemahaman terhadap masalah, pengetahuan bermakna yang termuat dalam masalah, pengetahuan mengenai strategi atau pendekatan pemecahan masalah, atau pengalaman sebelumnya dalam memecahkan masalah yang diinternalisasi menjadi pengetahuan (Mairing, Budayasa, \& Juniati, 2012).

\section{SIMPULAN}

Hasil penelitian ini menunjukkan bahwa rata-rata skor kemampuan siswa dalam memecahkan masalah sebesar 4,63 jika dikonversi ke skala 100 menjadi 28,9. Lebih lanjut, hanya ada satu siswa yang mampu menyelesaikan Masalah 1 dengan dua cara berbeda. Penyelesaiannya didasarkan pada pemahamannya terhadap masalah dan konsep-konsep yang terkait dengan masalah. Pemahaman tersebut direpresentasikannya dalam gambar lingkaran. Siswa tersebut juga mampu menyelesaikan Masalah 2 dengan satu cara tertentu tetapi belum mampu menyelesaikannya dengan cara lainnya.

Pada Masalah 2, ada 92,5\% siswa yang mampu menyelesaikannya dengan tepat satu cara tertentu. Dengan kata lain, siswa tersebut belum mampu menyelesaikan Masalah ini dengan lebih dari satu cara. Kondisi ini terjadi karena penyelesaian siswa didasarkan hanya pada rumus atau prosedur tertentu. Siswa tersebut tidak berusaha memahami masalah dengan merepresentasikannya dalam bentuk gambar lingkaran, atau mengelaborasi antar pengetahuan untuk mengembangkan suatu rencana penyelesaian. 
Ini berarti tidak ada siswa yang mampu menyelesaikan Masalah 1 dan 2 dengan lebih dari satu cara. Siswa yang mampu menyelesaikan masalah dengan lebih dari satu cara telah memiliki kemampuan berpikir tertinggi dalam matematika yaitu berpikir kreatif. Dengan demikian, tidak ada siswa yang menjadi subjek dalam penelitian ini yang memiliki kemampuan berpikir tertinggi tersebut.

\section{DAFTAR PUSTAKA}

Ary, D., Jacobs, L. C., \& Sorensen, C. 2006. Introduction to research in education (8th ed.). Belmont, CA: Wadsworth.

Bush, W. S., \& Greer, A. S. (Eds.). 1999. Mathematics assessment. A practical handbook for grade 9-12. Reston, VA: The National Council of Teachers of Mathematics Inc.

Charles, R., Lester, F., \& O'Daffer, P. 1987. How to evaluate progress in problem solving. Reston, VA: The National Council of Teachers of Mathematics, Inc.

Hudojo, H. 2005. Kapita selekta pembelajaran matematika. Malang, Indonesia: UM.

King, F. J., Goodson, L., \& Rohani, F. 2016. Higher order thinking skills. Retrieved March 30, 2016, from http://www.cala.fsu.edu/files/higher_order_thinking_skills.pdf

Krulik, S., Rudnick, J., \& Milou, E. 2003. Teaching mathematics in middle schools. A practical guide. Boston, MA: Pearson Education Inc.

Mahendra, Y. B. 2015. Proses berpikir kreatif siswa kelas XA SMA Negeri 1 gedangan dalam memecahkan masalah matematika pada materi peluang dengan soal higher order thinking ditinjau dari tingkat berpikir kreatif. MATHEdunesa, 1(4).

Mairing, J. P. 2017. Kemampuan siswa SMA dalam menyelesaikan masalah sistem persamaan linear tiga variabel. Aksioma, 15-26. Retrieved from http://jurnal.untad.ac.id/jurnal/index.php/AKSIOMA/article/view/8365

Mairing, J. P., Budayasa, I. K., \& Juniati, D. 2011. Profil pemecahan masalah peraih medali OSN. Jurnal Pendidikan dan Pembelajaran, 18(1), 65-71. Retrieved from http://journal.um.ac.id/index.php/pendidikan-danpembelajaran/article/viewFile/2758/508

Mairing, J. P., Budayasa, I. K., \& Juniati, D. 2012. Perbedaan profil pemecahan masalah peraih medali OSN matematika berdasarkan jenis kelamin. Jurnal Ilmu Pendidikan, 18(2), 125134. doi:10.17977/jip.v18i2.3612

Marzano, R. J., Pickering, D., \& McTighe, J. 1993. Assessing student outcomes. Alexandria, VA: Association for Supervision and Curriculum Development.

Matlin, M. W. 1994. Cognition (4 ed.). Orlando, FL: Harcourt Brace \& Company.

Ministry of Education. 2006. A guide to effective instruction in mathematics kindergarten to grade 6, volume two: Problem solving and communication. Toronto, Canada: Ontario Ministry of Education. 
National Council of Teachers of Mathematics [NCTM]. 2000. Principles and standards for school mathematics. Reston, VA: The National Council of Teachers of Mathematics, Inc.

Ontario Ministry of Education. 2006. A guide to effective instruction in mathematics kindergarten to grade 6, volume two: Problem solving and communication. Toronto, Canada: Ontario Ministry of Education.

Polya, G. 1973. How to solve it (2 ed.). Princeton, NJ: Princeton University Press.

Posamenteir, A. S., \& Krulik, S. 2009. Problem solving in mathematics grades 3-6, powerful strategies to deepen understanding. Thousand Oaks, CA: Corwin A SAGE Company.

Sa'dijah, C., \& Sukoriyanto. 2015. Asesmen pembelajaran matematika. Malang, Indonesia: UM Press.

Sternberg, R. J., \& Sternberg, K. 2012. Cognitive psychology (6 ed.). Belmont, CA: Wadsworth Cengage Learning. 